\title{
Ouabain potentiates the antimicrobial activity of aminoglycosides against Staphylococcus aureus
}

\author{
Neelam Kumari ${ }^{1}$, Snehlata Singh ${ }^{1}$, Vandana Kumari ${ }^{1}$, Siddhartha Kumar ${ }^{1}$, Vinay Kumar $^{2}$ and Antresh $\operatorname{Kumar}^{1 *}$ (D)
}

\begin{abstract}
Background: Staphylococcus aureus is a notorious pathogen which often causes nosocomial and community attained infections. These infections steadily increased after evolving the resistance due to indecorous practice of antibiotics and now become a serious health issue. Ouabain is a $\mathrm{Na}^{+} / \mathrm{K}^{+}$-ATPase inhibitor that leads to increase the heart contraction in patients with congestive heart failure.

Methods: In the present study, in vitro antimicrobial effect of ouabain together with aminoglycosides was determined against clinical and non-clinical S. aureus strains. Using checkerboard, Gentamycin uptake and biofilm assays, we analysed he interactions of ouabain with aminoglycosides.

Results: Ouabain induced the staphylocidal potency of aminoglycosides by remarkably reducing the MIC of gentamycin (GEN) by $16(0.25 \mu \mathrm{g} / \mathrm{mL}), 8$ folds $(0.5 \mu \mathrm{g} / \mathrm{mL})$ amikacin (AMK); and 16 folds $(1.0 \mu \mathrm{g} / \mathrm{mL})$ with kanamycin $(\mathrm{KAN})$, compared to their individual doses. OBN severely reduced cell viability within 60 min with GEN $(1 \mu \mathrm{g} / \mathrm{mL}), \mathrm{KAN}(2 \mu \mathrm{g} / \mathrm{mL})$ and 90 min with AMK $(1 \mu \mathrm{g} / \mathrm{mL})$. This bactericidal effect was enhanced due to GEN uptake potentiated by $66 \%$ which led to increase the cell permeability as revealed by leakage of bacterial ATP and nitrocefin assay. The biofilm adherence disrupted by 80 and $50 \%$ at $5 \mathrm{mg} / \mathrm{mL}$ and $1.5 \mathrm{mg} / \mathrm{mL}$ OBN and 50 and $90 \%$ biofilm formation was inhibited at $5 \mathrm{mg} / \mathrm{mL}\left(\mathrm{MBIC}_{50}\right)$ and 10 $\mathrm{mg} / \mathrm{mL}\left(\mathrm{MBI} \mathrm{C}_{90}\right)$, respectively. Moreover, OBN with GEN further induced biofilm inhibition by $67 \pm 5 \%$ at pH 7.0.

Conclusions: Taken together, we established that OBN synergizes the antimicrobial activity of aminoglycosides that induces cell killing due to intracellular accumulation of GEN by disturbing cell homeostasis. It may be proven an effective approach for the treatment of staphylococcal infections.
\end{abstract}

Keywords: Ouabain, Staphylococcus aureus, Synergism, Aminoglycosides, Gentamycin uptake, Biofilm inhibition, Antimicrobial activity, Biofilm detachment

\section{Background}

Superficial and invasive infections caused by Staphylococcus aureus continue to raise serious health challenges globally. These acute and chronic infections have now become more problematic after emerging multi-drug resistance (MDR) against various frontline antibiotics [1]. The problem of MDR in S. aureus is subsequently emerging both in nosocomial and hospital-acquired settings, with a significantly higher mortality and morbidity rate $[2,3]$. The condition of drug resistance is primarily developed by

\footnotetext{
* Correspondence: antreshkumar@cub.ac.in

${ }^{1}$ Department of Biotechnology, Central University of South Bihar,

Panchanpur, Gaya, Bihar 824236, India

Full list of author information is available at the end of the article
}

unregulated sales of antibiotics, a long course of medication, indiscriminate usage of drugs and poor public health infrastructure. Statistically, incidences of methicillinsensitive $S$. aureus (MSSA), methicillin-resistant $S$. aureus (MRSA) and vancomycin-resistant S. aureus (VRSA) infections have been endemic as it steadily increased up to $54 \%$ [4-6]. According to Indian hospitals survey, over $80 \%$ clinical samples of $S$. aureus were established resistance to the frontline antibiotics including methicillin [7]. However, the prevalence of MSRA infection in the U.S. accounts for 94,000 cases and over $\sim 18,000$ deaths per year [8]. Despite it, readily biofilm formation on the medical devices and host tissues also contribute to the persistent chronic infections. Biofilm embedded

(c) The Author(s). 2019 Open Access This article is distributed under the terms of the Creative Commons Attribution 4.0 International License (http://creativecommons.org/licenses/by/4.0/), which permits unrestricted use, distribution, and reproduction in any medium, provided you give appropriate credit to the original author(s) and the source, provide a link to the Creative Commons license, and indicate if changes were made. The Creative Commons Public Domain Dedication waiver (http://creativecommons.org/publicdomain/zero/1.0/) applies to the data made available in this article, unless otherwise stated. 
S. aureus remarkably decreased antibiotic and immune-defence susceptibility by over 100 folds and making them difficult to treat clinically $[9,10]$. The process of biofilm formation is multifactorial among which polysaccharide intercellular antigen (PIA) synthesized from UDP-N-acetylglucosamine via intercellular adhesion (icaADBC) locus play an important role. It has been reported that point mutant in the ica $A D B C$ locus abrogated the capacity of biofilm formation in $S$. aureus [11]. In contrast, secretions of virulence factors during different growth phase also contribute to biofilm formation [12]. Combating this notorious infection remains a major challenge as most of the conventional antibiotics have now become redundant to work and an immediate treatment regimen required for its elimination. Much efforts have gone into devising a workable treatment against staphylococcal infections particularly for the elimination of MRSA, VRSA pathogens by 1) searching a new antimicrobial from different sources 2) repurposing a new therapeutic property of the known drugs 3) synergizing the efficacy of the antibiotics with combination of others. Identification of the new antimicrobials via de novo synthesis and screening are a slow, costly and traditional approach. Most of the on-going research work to identify a new antimicrobial is focused on to repurposing existing drugs with known therapeutic property and toxicity that remarkably reduce treatment cost and side-effects with an antibiotic development. Simvastatin which originally used for the treatment of cardiovascular disease as it decreases the cholesterol level has also showed antimicrobial property against list of Gram-positive pathogens [13]. Similarly, anti-inflammatory, anti-oxidant ebsleen, antineoplastic 5-fluoro-2'-deoxyuridine (FdUrd) and antirheumatoid auranofin have also been reported to possess a strong bactericidal effect on drug-resistant; MRSA and VRSA strains [13, 14]. Combining two or more therapeutic agents is another lucrative approach for synergizing treatment and promptly elimination of pathogens by reducing the antibiotics load of the individual drug. Interactions between different antibiotics pair were found be synergistic against MSSA, MRSA, and Pseudomonas acquired infections. Plectasin paired either with $\beta$-lactam or aminoglycoside, Vancomycin increased potency of gentamycin, Nordihydroguaiaretic acid enhanced antimicrobial activity of aminoglycosides, glycerol monolaurate (GML) and lauric acid either with streptomycin or gentamicin are such examples [15-17]. In addition, the synergistic interaction of antibiotic with a variety of different compounds has also been reported. For example, hydroisothiocynates synergistically inhibited the growth of $S$. aureus with streptomycin. The polymyxin B boosted doxycycline and trgecycline activity against doxycycline-resistant and susceptible $K$. pneumoniae clinical isolates [18].
Ouabain or g-strophanthin is a cardiotonic steroid [19], derived from the plants (Strophanthus gratus, Acokanthera schimperi) or secreted endogenously by the adrenal glands [20]. It acts on $\alpha$-subunit of $\mathrm{Na}^{+} / \mathrm{K}^{+}$-ATPase to inhibit its transport activity resulting in an increase intracellular sodium ion $\left(\mathrm{Na}^{+}\right)$concentration $[21,22]$. The physio-pathological role of ouabain is linked to increase the heart contraction in patients with congestive heart failure [23]. However, disruption of $\mathrm{Na}^{+} \mathrm{K}^{+}$-ATPase activity leads to disturb membrane polarity with subsequent accumulation of intracellular $\mathrm{Ca}^{2+}$ level and neurotransmitter release [24]. A group of studies has demonstrated that ouabain also promotes different types of cell proliferation [25-29] and cell susceptibility against different microbes [30]. However, the efficacy of ouabain on persistent $S$. aureus biofilm and functional mechanism for the treatment of Staphylococcal infection has not elucidated so far. With this background, the aim of the present study is to evaluate in vitro activity of ouabain together with aminoglycosides (GEN, KAN, AMK) and other antibiotics (AMP, TET, VAN) against $S$. aureus.

\section{Methods}

\section{Chemicals, Bacteria strains, and media}

Ouabain (OBN) and ATP (adenosine 5'-triphosphate), FITC (fluorescein isothiocyanate), Crystal violet, used in this study were purchased from the Sigma Aldrich (St. Louis, MO). Antibiotics such as ampicillin (AMP), tetracycline (TET), vancomycin (VAN), gentamycin (GEN), amikacin (AMK) and kanamycin (KAN) was procured from HiMedia (Mumbai, India).

The methicillin-sensitive S. aureus (MSSA); ATCC29213 was used in this study. Clinical $S$. aureus strains IGMS 002 and IGMS 007 received a kind gift from the Indira Gandhi Institute of Medical Science (IGIMS), Patna, were used for cell susceptibility analysis. Muller Hinton Agar/ Broth (MHA/MHB) and Tryptic Soya Broth (TSB) were used to culture $S$. aureus and biofilm formation, respectively at $37^{\circ} \mathrm{C}$. Culture media was purchased from the Himedia Laboratory.

\section{Spot assay}

The antimicrobial susceptibility of OBN alone or in combination of tested antibiotics (AMP, TET, VAN, GEN, AMK and KAN) was determined as described earlier [31, 32]. Briefly, both ATCC 29213 and clinical isolates (IGMS02 and IGMS07) of S. aureus were cultured in Muller-Hinton broth (MHB) till the cell density achieved the exponential stage $\left(\mathrm{OD}_{600 \mathrm{~nm}}\right.$ reaches 0.5$)$. Cells were then resuspended into $1 \mathrm{X}$ phosphate buffer saline $\mathrm{pH} 7.4(\mathrm{PBS})$ to maintain cell density $0.1 \mathrm{OD}_{600 \mathrm{~nm}}$ $\left(2 \times 10^{8}\right.$ cells $\left./ \mathrm{mL}\right)$ for spotting. $5 \mu \mathrm{L}$ of five folds serial dilutions were spotted on MHA plate containing AMP $(0.125 \mu \mathrm{g} / \mathrm{mL})$, TET $(1.5 \mu \mathrm{g} / \mathrm{mL})$, VAN $(0.5 \mu \mathrm{g} / \mathrm{mL})$, GEN 
$(1.0 \mu \mathrm{g} / \mathrm{mL})$, AMK $(1.0 \mu \mathrm{g} / \mathrm{mL}), \mathrm{KAN}(1.0 \mu \mathrm{g} / \mathrm{mL})$ alone or with $1 \mathrm{mg} / \mathrm{mL}$ OBN. The difference in $S$. aureus cell growth was observed after incubation for $16 \mathrm{~h}$ at $37^{\circ} \mathrm{C}$.

\section{Chequerboard assay}

The interaction of OBN with panel of antibiotics; AMP, TET, GEN, AMK, GEN, and KAN, was determined by the chequerboard method as described elsewhere with minor modifications [33]. The interactions between two tested antibiotics combinations were represented by fractional inhibitory concentration (FIC) index for each agent. The FIC can be expressed as the sum of MIC (minimal inhibitory concentration) of two tested agents in combination divided by the MIC of the individual agent. Briefly, two folds of serial dilutions of tested antibiotics were made $(\mathrm{mg} / \mathrm{mL})$ such as $0.062-32$ (GEN and AMK), 0.00025-0.128 (KAN), 0.000004-0.002 (AMP), 0.000016-0.008 (VAN and TET) and 1.4-128 (OBN) and latter $100 \mu \mathrm{L}\left(5 \times 10^{4}\right.$ cells $\left./ \mathrm{mL}\right)$ S. aureus cells suspension was added to each well and cultured for $48 \mathrm{~h}$ at $37^{\circ} \mathrm{C}$. The MIC value of each tested agent was observed by measuring the optical density at $\mathrm{OD}_{600 \mathrm{~nm}}$. Each chequerboard test generates many different combinations and by convention, the FIC value of the most effective combination is used by calculating the fractional inhibitory concentration index (FICI). FICI was calculated by adding both FICs:

$\mathrm{FICI}=\mathrm{FIC}_{\mathrm{A}}+\mathrm{FIC}_{\mathrm{B}}=\left(\mathrm{C}_{\mathrm{A}}{ }^{\text {comb }} / \mathrm{MIC}_{\mathrm{A}}{ }^{\text {alone }}\right)+\left(\mathrm{C}_{\mathrm{b}}{ }^{\text {comb }} / \mathrm{MIC}_{\mathrm{B}}{ }^{\text {alone }}\right)$

Where, MIC A alone and MIC B alone are the MICs of drugs $\mathrm{A}$ and $\mathrm{B}$ when acting alone and $\mathrm{C}_{\mathrm{A}}{ }^{\text {comb }}$ and $\mathrm{C}_{\mathrm{b}}{ }^{\text {comb }}$ are concentrations of drugs $\mathrm{A}$ and $\mathrm{B}$ at the isoeffective combinations, respectively. Synergism interactions between two tested agents were interpreted in terms of FICI value when it is $<0.5$, indifferent between $\geq 0.5$ to $<2$, and antagonistic when it was $4[34,35]$.

\section{Cell viability assay}

To analyse the staphylocidal activity of Ouabain (OBN) in combination with tested antibiotics, $2 \times 10^{6}$ mid-log phase cells were taken as described elsewhere [31]. The cells were treated with a fix $1 \mathrm{mg} / \mathrm{mL} \mathrm{OBN}$, in absence or presence of $0.25 \mathrm{X}$ MIC of GEN $(1.0 \mu \mathrm{g} / \mathrm{mL})$, AMK $(1.0 \mu \mathrm{g} / \mathrm{mL})$ and KAN $(2.0 \mu \mathrm{g} / \mathrm{mL})$. After the cell treatment, it was kept at $37{ }^{\circ} \mathrm{C}$ at $120 \mathrm{rpm} .10 \mu \mathrm{L}$ of cell fractions were taken intermittently after each $2 \mathrm{~h}$ intervals. Cell fractions were serially diluted up to 1000 folds with $1 \mathrm{X}$ PBS to reduce drug concentration. The viable colonies were calculated after overnight incubation at $37^{\circ} \mathrm{C}$. Percentage of cell killing of treated samples was calculated with respect to the untreated samples (control) using formula (No. of CFU obtained in treated sample/ No. of CFU obtained in control sample) $\times 100$.

\section{Membrane permeability assay}

The membrane permeabilizing property of OBN against $S$. aureus was determined by two different methods mentioned hereunder: ATP leakage assay: Briefly, $S$. aureus cells were harvested to mid-exponential phase and diluted to maintain $1 \times 10^{6}$ cells $/ \mathrm{mL}$ in $50 \mathrm{mM}$ Tris$\mathrm{Cl}, \mathrm{pH} 7.5 ; 135 \mathrm{mM} \mathrm{NaCl}$ supplemented with $1 \mathrm{mg} / \mathrm{mL}$ OBN in absence or presence of $1 \mu \mathrm{g} / \mathrm{mL}$ GEN. Cells were also treated with $35 \mu \mathrm{g} / \mathrm{mL}$ Gramicidin B, which acts as a positive control. During analysis, $100 \mu \mathrm{L}$ sample was withdrawn at $15 \mathrm{~min}$ intervals and supernatants were recovered by centrifugation for measurement of ATP leaks out during treatment [16]. The amount of ATP leakage was quantified upon its hydrolysis into inorganic phosphate at $750_{\mathrm{nm}}$. The ATPase assay was perfumed using purified Nucleotide Binding Domain 1(NBD-1) of Candida drug resistance $1(\mathrm{Cdr} 1)$ protein of Candida albicans [36]. Nitrocefin disc assay: The cell permeabilization of $S$. aureus was determined by measuring the nitrocefin hydrolysis assay by cellular betalactamase as described elsewhere [37]. Briefly, overnight aged $S$. aureus cells were treated with $1 \mathrm{mg} / \mathrm{mL}$ OBN alone or in combination with $2 \mu \mathrm{g} / \mathrm{mL}$ GEN. During analysis, $100 \mu \mathrm{L}$ sample was withdrawn after $60 \mathrm{~min}$ and supernatant was recovered by centrifugation at 10,000 $\mathrm{rpm}$. Alteration in colour from yellow to red shows nitrocefin hydrolysis which was monitored spectrophotometrically at $485 \mathrm{~nm}$ and also quantified yellow to red disc colour change using Image J.

\section{Gentamicin (GEN) uptake assay}

The cell culture was harvested to mid-exponential phase and cell suspension was made to maintain cell concentration $0.5 \mathrm{OD}\left(1 \times 10^{8}\right.$ cells $\left./ \mathrm{mL}\right)$ with $1 \mathrm{X}$ PBS. The cells were kept on starvation at $37^{\circ} \mathrm{C}$ for $1 \mathrm{~h}$ on mild shaking conditions which were treated with $2 \mathrm{mg} / \mathrm{mL}$ OBN for $45 \mathrm{~min}$ at $37^{\circ} \mathrm{C}$ in the absence or presence of $10 \mathrm{mM}$ Glucose followed by addition $1 \mu \mathrm{g} / \mathrm{mL}$ GEN alone or in combination with crude cell membrane isolated from $S$ aureus. Cells were treated further for $15 \mathrm{~min}$. The supernatant was recovered by centrifugation $(8000 \mathrm{rpm}, 2 \mathrm{~min}$ at $4{ }^{\circ} \mathrm{C}$ ) after $5 \mathrm{~min}$ incubation on ice. Both starved and non-starved cells were used for GEN uptake. Absorbance was measured at $202_{\mathrm{nm}}$ to estimate the extracellular GEN concentration [38].

\section{Preparation of crude cell membrane (CE)}

Briefly, $5 \mathrm{~mL}$. aureus cells were harvested to midexponential phase and resuspended in $1 \mathrm{~mL}, 1 \mathrm{X}$ PBS containing $1 \%$ TritonX-100. Cells were disrupted by sonication at $30 \mathrm{~s}$ pulse followed by $1 \mathrm{~min}$ rest, repeated 4 cycles on ice. The supernatant was recovered by centrifugation at $4000 \mathrm{rpm}$ and $4{ }^{\circ} \mathrm{C}$ for $10 \mathrm{~min}$ followed by high-speed centrifugation at $18000 \mathrm{rpm}$ and $4{ }^{\circ} \mathrm{C}$ for 45 
min [39]. The pellet was suspended in 1X PBS and stored at $-20^{\circ} \mathrm{C}$ for GEN uptake analysis.

\section{Cell attachment assay}

The cell adherence effect of OBN was determined by crystal violet staining and FITC labelling. Crystal violet cell adherence assay: Briefly, S. aureus cells were harvested to mid-exponential phase and diluted to maintain $2 \times 10^{5}$ cells $/ \mathrm{mL}$ in TSB containing $5 \mathrm{mM}$ glucose. $200 \mu \mathrm{L}$ cell suspension was taken in sterile 96 wells polystyrene plate. The biofilm attachment was also analysed on sterile glass slide $(10 \times 10 \mathrm{~mm})$ put in the wells and varying OBN concentration $(\mathrm{mg} / \mathrm{mL})$ from 0.5 to 5 were added for $3 \mathrm{~h}$ at $37^{\circ} \mathrm{C}$. The OBN untreated $S$. aureus cells were considered as a control. Unbound cells washed with PBS and fixed using 100\% methanol for 15 min. The glass slide and plate wells both were stained with $200 \mu \mathrm{L}$ of $0.1 \%(\mathrm{v} / \mathrm{v})$ crystal violet for $5 \mathrm{~min}$. Excess stain was gently rinsed off. The biofilm attachment on glass slide was observed under inverted microscope. The optical density of wells was measured at $\mathrm{OD}_{595 \mathrm{~nm}}$ in 96 well plate reader after re-solubilization biofilm in $200 \mu \mathrm{L}, 95 \%(\mathrm{v} / \mathrm{v})$ ethanol [40].

\section{FITC cell adherence assay}

Briefly, $5 \mathrm{~mL} S$. aureus cells were harvested to midexponential phase to maintain $1 \times 10^{8}$ cells in $1 \mathrm{~mL}, 1 \mathrm{X}$ PBS. For FITC labelling, cells were incubated overnight at $4{ }^{\circ} \mathrm{C}$ with FITC $(1.0 \mathrm{mg} / \mathrm{mL})$ with gentle stirring and rinsed off unbound FITC with PBS. The glass slide pretreated overnight at $4{ }^{\circ} \mathrm{C}$ in the presence or absence of blood plasma were put into $200 \mu \mathrm{L}$, FITC labelled cells seeded in the 24 wells polystyrene plate. The plate was incubated for $30 \mathrm{~min}$ at $37^{\circ} \mathrm{C}$ with or without OBN (5.0 $\mathrm{mg} / \mathrm{mL}$ ). Thereafter, cover slides were repeatedly washed with PBS and observed under inverted fluorescence microscope [40].

\section{Inhibition of biofilm formation}

The effect of OBN on biofilm inhibition was determined as described elsewhere [31, 41, 42]. Briefly, $2 \times 10^{5}$ cells from the overnight $S$. aureus culture were incubated in glucose $(5 \mathrm{mM})$ containing TSB of three different $\mathrm{pH}$ i.e. 7.0, 6.0 and 5.0 for biofilm formation. Biofilm was grown on microliter plate well and sterile glass-slide $(10 \times 10$ $\mathrm{mm}$ ) placed in 24 wells polystyrene plate. Biofilm was treated with subsequent increasing concentration of OBN ranges from 1 to $5 \mathrm{mg} / \mathrm{mL}$, added individually or with GEN $(1 \mu \mathrm{g} / \mathrm{mL})$ at $37^{\circ} \mathrm{C}$ for different time periods (24h \& $72 \mathrm{~h})$. After incubation, both wells and glass slides were washed with $1 \mathrm{X}$ PBS to remove planktonic bacteria. The cells were then fixed with $200 \mu \mathrm{L}$ methanol for $15 \mathrm{~min}$ and plates were allowed to dry. The slide and plate well, both were stained with $200 \mu \mathrm{L}$ of $0.1 \%$ (w/v) crystal violet for $5 \mathrm{~min}$. Excess stain was gently rinsed off and plates were air-dried. After staining, biofilm was observed under the inverted microscope or resolubilization in $200 \mu \mathrm{L}, 95 \%(\mathrm{v} / \mathrm{v})$ ethanol and concentration was measured at $\mathrm{OD}_{595 \mathrm{~nm}}$ for biofilm inhibition analysis. The OBN untreated $S$. aureus cells were considered as a positive control in both experiments.

\section{Statistical analyses}

Statistical analyses were assessed using GraphPad prism 6.0 (Graph Pad Software, La Jolla, CA). P values were calculated via Student t-test and Avova test.

\section{Results}

Ouabain synergizes $S$. aureus susceptibility to aminoglycosides

Ouabain (OBN) is a known $\mathrm{Na}^{+}-\mathrm{K}^{+}$-ATPase pump inhibitor which leads to disturb membrane integrity of the eukaryotic cell. As a result, it causes cell damage via plasma membrane depolarization (PMD). To confirm the killing effect of OBN, spot assay was performed using two different OBN concentrations; 1.0 and $10 \mathrm{mg} /$ $\mathrm{mL}$ against methicillin-sensitive $S$. aureus (MSSA); ATCC 29213 and S. aureus clinical isolates, IGMS 002 and IGMS 007. No effect on cell susceptibility was observed even though at higher OBN concentration (Fig. 1a). Combining more than one antibiotic is considered to be more effective to control notorious pathogens. To find out whether OBN combined with conventional antibiotics may lead any alteration in drug susceptibility. The activity of OBN in combination with ampicillin (AMP), tetracycline (TET), vancomycin (VAN), and known aminoglycosides; gentamycin (GEN), amikacin (AMK), kanamycin (KAN) were determined using broth microdilution checkerboard assay against $S$. aureus. The fractional inhibitory concentration (FIC) index for these combinations was calculated which was shown in Table 1. In combination with OBN, MIC was remarkably reduced by $16(0.25 \mu \mathrm{g} / \mathrm{mL}), 8(0.5 \mu \mathrm{g} / \mathrm{mL})$ 16 folds $(1.0 \mu \mathrm{g} / \mathrm{mL})$ for GEN, AMK and KAN, respectively and thereby demonstrated synergistic effect with aminoglycosides. The $1.0 \mathrm{mg} / \mathrm{mL}$ of the lowest concentration of OBN was enabled to stimulate the most synergistic effect with aminoglycosides. Of note, no such synergistic interactions were observed with AMP, TET and VAN. To validate the synergistic effect of OBN with aminoglycosides, spot assay further visualized the interaction of OBN with GEN, AMK, and KAN when a fix $1.0 \mu \mathrm{g} / \mathrm{mL}$ of GEN, AMK, and KAN supplemented with $1.0 \mathrm{mg} / \mathrm{mL} \mathrm{OBN}$ that It noticeably hyper-susceptible to these aminoglycosides than the individual effects of antibiotics (Fig. 1b). We did not find antagonistic interactions between OBN and any of the drugs tested. 


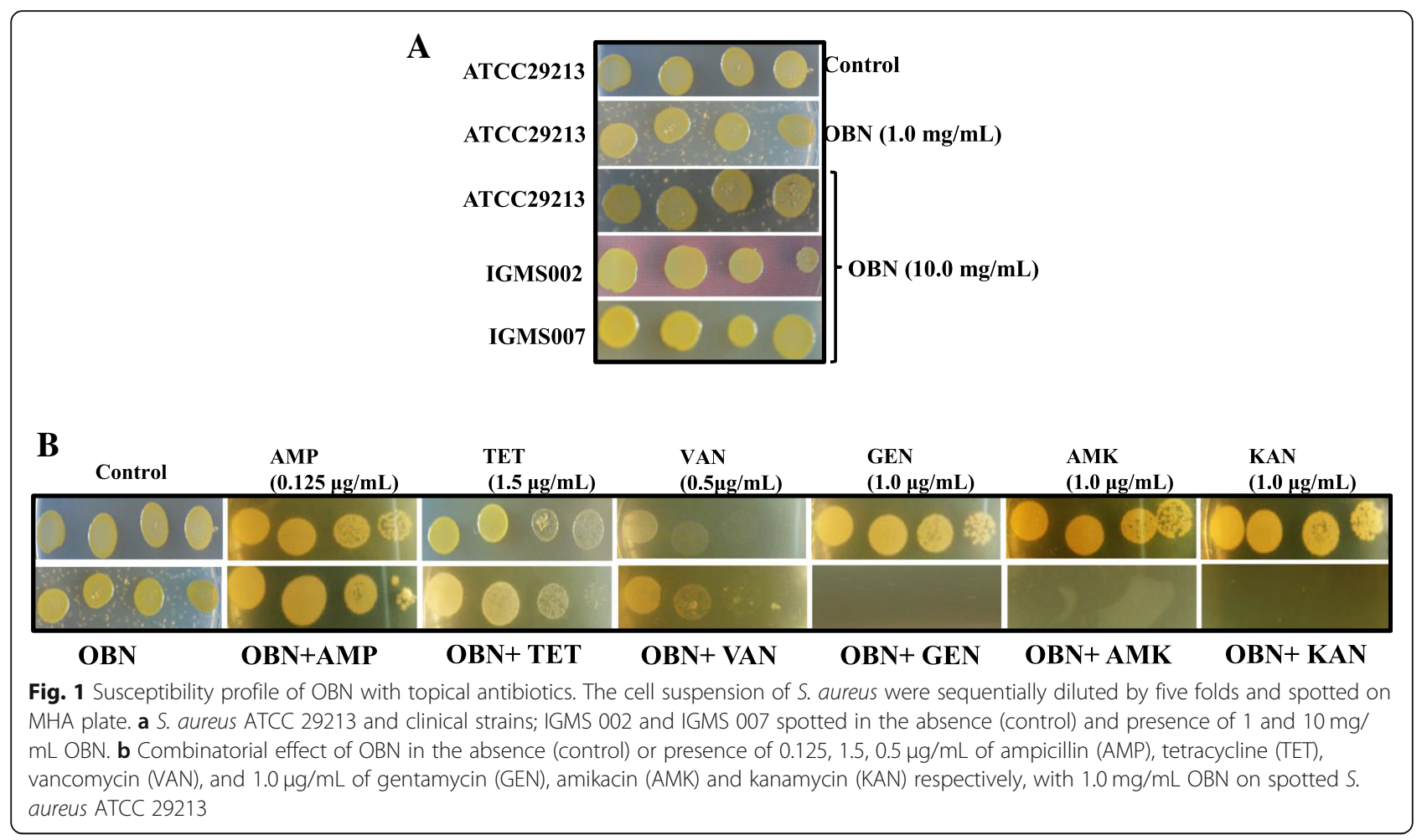

\section{Cell viability confirms synergism}

To assess the growth inhibition of $S$. aureus was a result of cell killing when OBN supplemented with aminoglycosides (GEN, AMK, and KAN) in the medium. A midexponential stage cells were treated with a fix $1.0 \mathrm{mg} / \mathrm{mL}$ OBN and $0.25 \mathrm{X}$ MIC of aminoglycosides alone or in combination with them. Figure 2 illustrates that GEN $(1 \mu \mathrm{g} / \mathrm{mL})$, AMK $(1 \mu \mathrm{g} / \mathrm{mL})$ and KAN $(2 \mu \mathrm{g} / \mathrm{mL})$ at $0.25 \mathrm{X}$ MIC initially affects cell viability which tends to

Table 1 Checkerboard assay of GEN, AMK, KAN, AMP, VAN, TET and OBN against $S$. aureus

\begin{tabular}{|c|c|c|c|c|c|}
\hline \multirow{2}{*}{$\begin{array}{l}\text { Antimicrobial } \\
\text { agents }\end{array}$} & \multicolumn{3}{|c|}{ MIC of each agent $(\mu \mathrm{g} / \mathrm{mL})$} & \multirow[b]{2}{*}{$\mathrm{FICl}$} & \multirow[b]{2}{*}{ Outcome } \\
\hline & alone & Comb & $\mathrm{FIC}$ & & \\
\hline GEN & 4 & 0.25 & 0.0625 & & \\
\hline OBN & 32000 & 1000 & 0.03125 & 0.0937 & Syn \\
\hline AMK & 4 & 0.5 & 0.125 & & \\
\hline OBN & 32000 & 1000 & 0.03125 & 0.1562 & Syn \\
\hline KAN & 16 & 1 & 0.0625 & & \\
\hline OBN & 32000 & 2000 & 0.0625 & 0.125 & Syn \\
\hline AMP & 0.5 & 0.25 & 0.5 & & \\
\hline OBN & 32000 & 8000 & 0.25 & 0.75 & $\mathrm{NI}$ \\
\hline VAN & 1 & 0.25 & 0.25 & & \\
\hline OBN & 32000 & 16000 & 0.5 & 0.75 & $\mathrm{NI}$ \\
\hline TET & 2 & 0.5 & 0.25 & & \\
\hline OBN & 32000 & 8000 & 0.25 & 0.5 & $\mathrm{NI}$ \\
\hline
\end{tabular}

Syn Synergism, NI No Interaction recover after $4 \mathrm{~h}$ of the treatment. In contrast, cells were found to be completely killed with no significant viable cells $( \pm 2 \%)$ within $90 \mathrm{~min}$ exposure of OBN, combined either with GEN or KAN respectively and similar effect was also observed within $60 \mathrm{~min}$ in presence of OBN supplemented with AMK. No such cell viability was recovered even OBN long exposure $(24 \mathrm{~h})$ supplemented with these aminoglycosides. These results ensure that the OBN potentiates bactericidal effect of tested aminoglycosides antibiotics i.e. GEN, AMK and KAN. Of note, the regrowth observed with single used of GEN, AMK and KAN was due to cell adaptation and /or overcome drug stress in the initial stage of growth condition.

\section{OBN potentiates gentamycin (GEN) uptake}

It has been well documented that uptake of aminoglycoside the cell is the proton motive force (PMF) dependent. Disturbance in PMF system by inhibiting electron transport severally abolished GEN uptake in eukaryotes. To explore the inhibitory effect of OBN on PMF, GEN uptake was determined using mid-log cells tested under two conditions; non-starved active or starved cells re-energized with glucose. An active mid$\log$ phase $S$. aureus cells were pre-incubated with 1.0 $\mathrm{mg} / \mathrm{mL}$ OBN for $30 \mathrm{~min}$ followed by $10 \mathrm{~min}$ GEN treatment. OBN that induced the cell killing with aminoglycosides (GEN, KAN and AMK), also significantly induces GEN uptake by 66\% (Fig. 3a) as compared to control (only GEN treated) $\left({ }^{*} P \leq 0.05\right)$. To further 

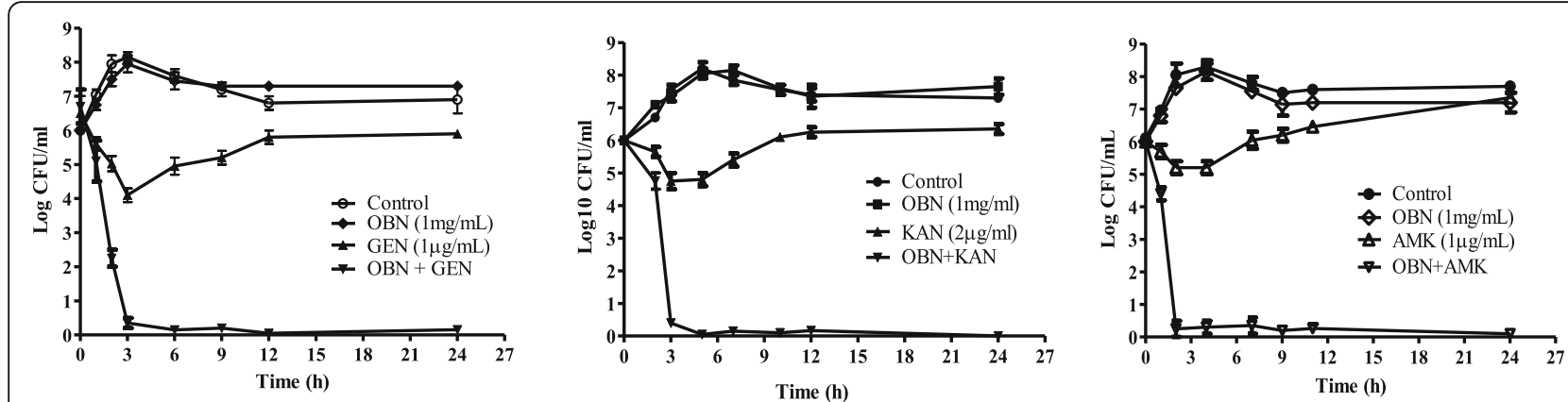

Fig. 2 Cell killing effect of OBN with aminoglycosides. The bactericidal effect was measured by treating S. aureus ATCC29213 cells for different time course in the absence or presence of $1 \mathrm{mg} / \mathrm{mL}$ OBN alone or with GEN $(1.0 \mu \mathrm{g} / \mathrm{mL})$, AMK $(1.0 \mu \mathrm{g} / \mathrm{mL})$ and KAN $(2.0 \mu \mathrm{g} / \mathrm{mL})$. The cell viability was measured by diluting 10uL sample fraction by 1000 folds

confirm energy dependent GEN uptake, cells were starved for an hour in $1 \mathrm{X}$ PBS. The starved cells reenergized with glucose $(10 \mathrm{mM})$ remarkably increased GEN uptake by $50 \%$ with OBN, as compared to control. Of note, GEN uptake was found to be limited when starved cells (de-energized) were individually treated with OBN and glucose (Fig. 3b). Statistical analysis was performed via the two-tailed Student $t$ test. $P$ values of $(* * P \leq 0.01)$ are considered as significant. However similar restriction in GEN uptake was also observed when crude membrane (extracted from $S$. aureus) added into the both tested conditions (Fig. 3a, b). The intracellular accumulation of GEN is responsible for cell killing.

\section{Effect of $\mathrm{OBN}$ on cell permeabilization}

The complex composition of protein and lipids of the cell membrane makes it one of the most significant barriers that selectively allow molecules to pass through it. Any alteration in the cell membrane affects cell permeability. To confirm whether increased GEN uptake is the result of membrane alteration, cell permeabilization effect was determined by measuring the leakage of cellular ATP and hydrolysis of nitrocefin by whole cell. The membrane permeabilizing property of the OBN against S. aureus cell membrane, ATP leakage was measured using purified NBD1 ATPase protein. When cell membrane becomes more permeable, more amounts of ATP releases outside the cell that can be corroborated with
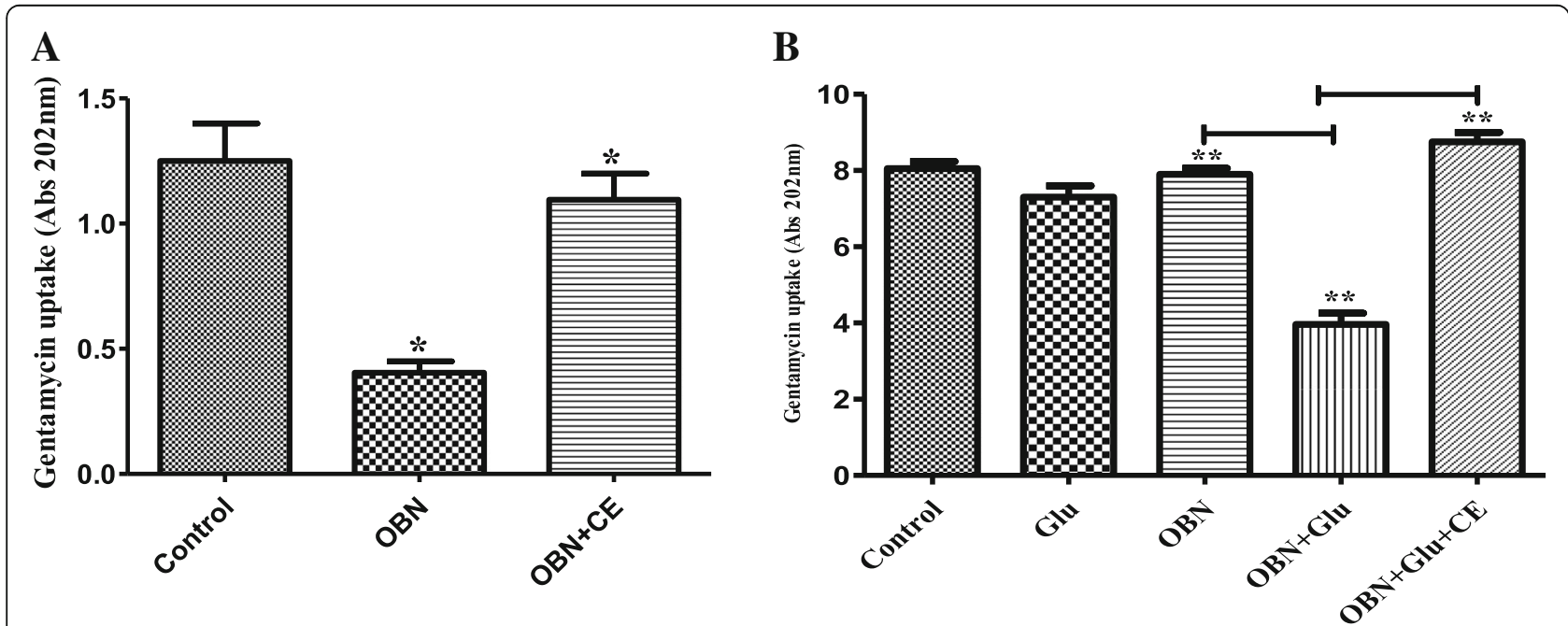

Fig. 3 OBN potentiates the gentamycin (GEN) uptake. The GEN (1 $\mu \mathrm{g} / \mathrm{mL}$ ) treated S. aureus ATCC29213 cells were incubated in the absence (control) or presence of OBN ( $2 \mathrm{mg} / \mathrm{mL}$ ) and measured extracellular GEN concentration. a Mid-log phase active cells used in the absence or presence of crude membrane (CE) with OBN. Two-tailed Student $t$ test was performed for statistical analysis. $P$ values of ( $\left.{ }^{*} P \leq 0.05\right)$ are considered as significant. $P$ values of control vs OBN: 0.032, OBN vs OBN + CE: 0.026 . b Starved cells re-energized with $10 \mathrm{mM}$ glucose (Glu) used in the presence and absence of crude membrane (CE). Statistical analysis was performed via the two-tailed Student $t$ test. $P$ values of (** $P \leq 0.01)$ are considered as significant. Detailed "P" values are control vs OBN + Glu: 0.0073, OBN vs OBN + Glu: 0.0072, OBN + Glu vs OBN + Glu + CE: 0.0065 
ATP dependent-ATPase activity. During analysis, different samples were withdrawn at $5 \mathrm{~min}$ intervals and supernatants used for measurement of leakage of cellular ATP. Cells treated with $0.25 \mathrm{X}$ MIC aminoglycosides (GEN, KAN and AMK) and OBN alone didn't significantly alter the cell permeability as low ATP activity was observed even at $20 \mathrm{~min}$ cells exposure. Similar to the positive control, $0.25 \mathrm{X}$ MIC of tested aminoglycosides; GEN $(1.0 \mu \mathrm{g} / \mathrm{mL})$, AMK $(1.0 \mu \mathrm{g} / \mathrm{mL})$, KAN $(2.0 \mu \mathrm{g} / \mathrm{mL})$ along with $1 \mathrm{mg} / \mathrm{mL}$ OBN treated cells exhibited a higher time-dependent activity with $35 \pm 5$ nmoles/mg/ min ATP activity at 20 min of exposure (Fig. 4a). The similar effect of OBN with GEN was also verified by nitrocefin assay as shown in Fig. 4b. These results indicate that leakage of more ATP is due to increased cell permeability. $P$ values of $(" P \leq 0.05)$ are considered as significant difference via the two-tailed Student $t$ test.

\section{OBN clears up the bacterial cell adherence}

Formation of biofilm over the cell boundary and expression of cell wall associated factors are accountable for pathogens adherence on different host tissue. Such bacterial adherence promotes the cell infections and causes a major hurdle in the antimicrobial treatment. To investigate the OBN effect on disruption of cell adherence (detachment), microliter dish biofilm assay was performed. Figure 5a illustrates that the biofilm attachment to the solid surface (polystyrene plate) was lost almost 80 and $50 \%$ when early exponential cells were treated with $5 \mathrm{mg} / \mathrm{mL}$ and $1.5 \mathrm{mg} / \mathrm{mL} \mathrm{OBN}$, respectively. The loss in cell attachment was further corroborated with FITC labelled and or blood plasma coated S. aureus cells
(Fig. 5b). As expected, OBN remarkably lost the cell adherence ability of $S$. aureus on the solid surface. Statistical analysis was performed via the two-tailed Student $t$ test. $P$ values of $(* P \leq 0.05, \& * P \leq 0.01)$ are considered as significant difference. These studies clearly demonstrate the role of $\mathrm{OBN}$ in the disruption of cell attachment to the adhered surface.

\section{OBN inhibits the biofilm formation}

To further evaluate OBN effect associated with the inhibition of biofilm formation, $S$. aureus cells grown in biofilm forming TSB medium with varying OBN concentration and biofilm mass was measured after $2 \mathrm{~h}$ of treatment. Figure $6 a$ illustrates that the biofilm formation was inhibited by 50 and $90 \%$ at $5 \mathrm{mg} / \mathrm{mL}\left(\mathrm{MBIC}_{50}\right)$ and $10 \mathrm{mg} / \mathrm{mL}\left(\mathrm{MBIC}_{90}\right) \mathrm{OBN}$, respectively after $24 \mathrm{~h}$ of OBN treatment. The biofilm inhibitory effect of OBN was further confirmed by microscopic analysis. Cells treated with $0.5 \mathrm{mg} / \mathrm{mL}$ and $5 \mathrm{mg} / \mathrm{mL}$ OBN reduced the biofilm cell aggregated by approximately 10 and 50\%, respectively compared to untreated (control) (Fig. 6b). Of note, the inhibition of biofilm formation tends to increase upon longer exposure greater than $48 \mathrm{~h}$ of OBN treatment (Fig. 6c). $P$ values of $(* P \leq 0.05),(* * P \leq 0.01)$ and $(* * P \leq 0.001)$ are considered as significant difference using two-tailed Student $t$ test. These results indicate that OBN inhibits biofilm formation at the initial stage more efficiently than the preformed matured one.

\section{$\mathrm{pH}$-dependent biofilm inhibition effect of OBN}

Henry-Stanley et al., investigated that the biofilm formation steadily decreases under acidic $\mathrm{pH}$. The $\mathrm{pH}$-dependent
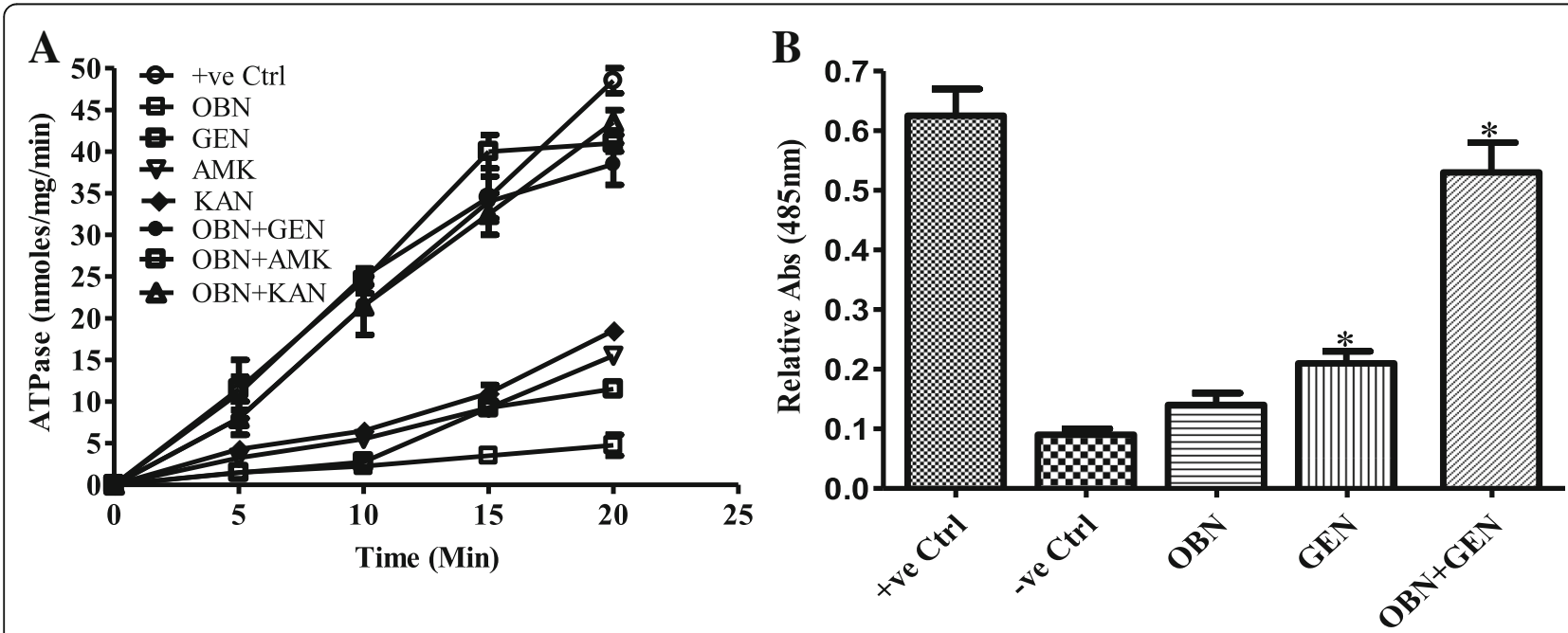

Fig. 4 Cell permeability effect of OBN with aminoglycosides. a S. aureus ATCC29213 cells treated in the absence (-ve control) and presence of OBN $(1 \mathrm{mg} / \mathrm{mL}$ ) and $0.25 X$ MIC of aminoglycosides (GEN, TET, AMK) either added alone or in combination. Gramicidin B was used as a positive (+ve) control. a Measured extracellular leakage of cellular ATP by ATPase assay at different time intervals. $\mathbf{b}$ Nitrocefin hydrolysis was measured with and without (-ve control) addition of GEN with OBN alone or combination after 60 min treatment. Statistical analysis confirmed a significant difference with "P" value, between control vs GEN: 0.033, control vs OBN + GEN: 0.013 and OBN vs OBN + GEN: 0.018 


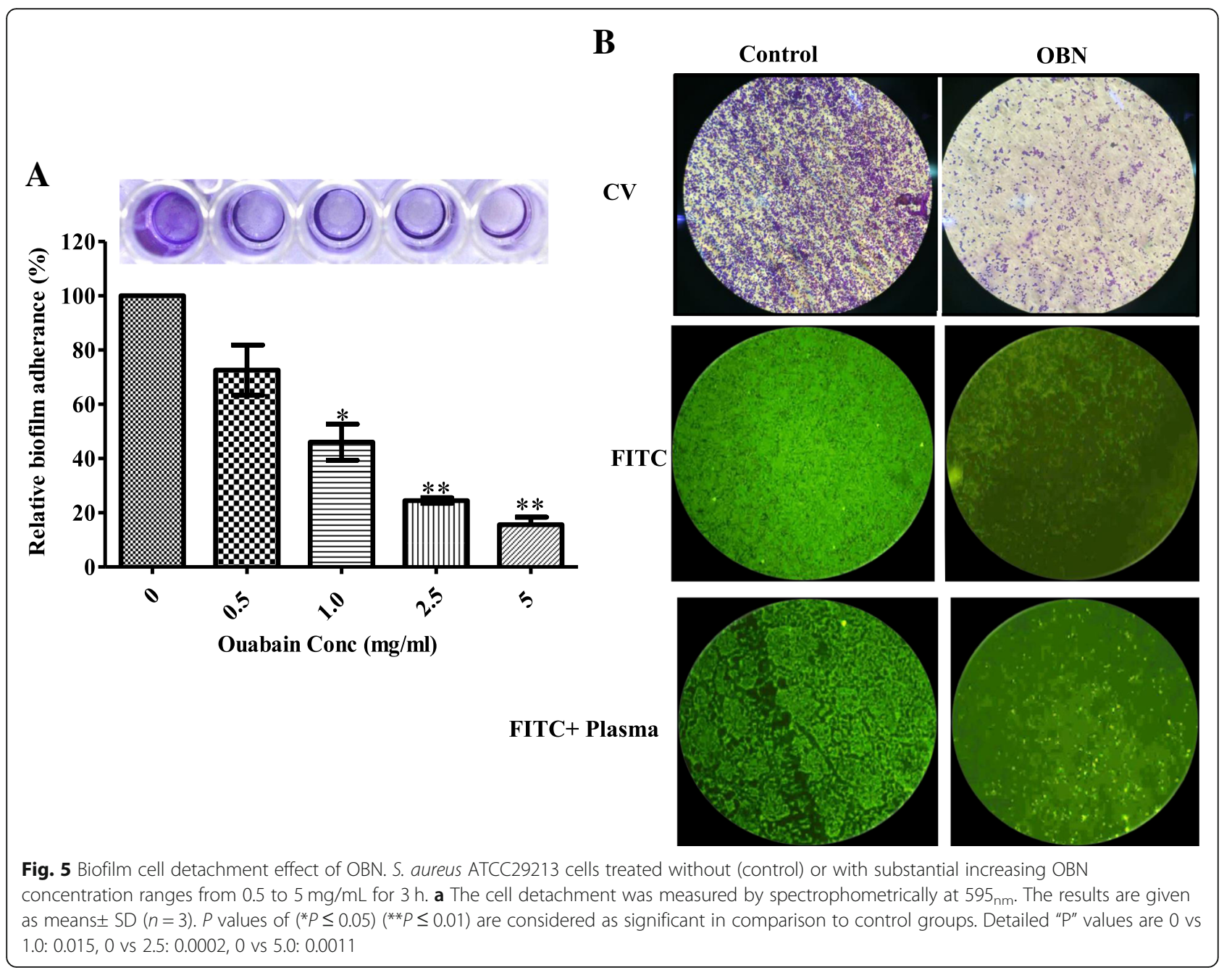

biofilm formation effect was investigated in the presence of OBN at three $\mathrm{pH}$ conditions i.e. $\mathrm{pH} 7.0,6.0,5.5$ which was normalized by cell viability. Biofilm grown for $24 \mathrm{~h}$ was treated with $1 \mathrm{mg} / \mathrm{mL}$ OBN and $1 \mu \mathrm{g} / \mathrm{mL}$ GEN individually or together. Biofilm formed was firmly adhered to the polystyrene coated plate at $\mathrm{pH} 7.0$ and it was loosely packed at acidic $\mathrm{pH}$. It was substantially reduced by $21 \pm 4 \%, 37 \pm 5 \%$ and $55 \pm 5 \%$ at $7.0,6.05 .5 \mathrm{pH}$ respectively when treated with OBN. At pH 7.0, the biofilm was synergistically reduced by $67 \pm 5 \%$ and no similar effect was observed at pH 6.0 and 5.5 when both OBN combined with GEN. Of note, S. aureus exhibited resistance to GEN at lower pH (Fig. 7). Statistical analyses were done using the two way Anova test. $P$ values of $(P \leq 0.05)(P \leq 0.01)$ are considered as significant.

\section{Discussion}

The therapeutic utilities of OBN have been explored against different medical issues $[24,25,28]$ but its biofilm inhibitory activity and antimicrobial synergism with topical antibiotics have unrevealed. In present in vitro study, we found that OBN boosted up the antibacterial activity of aminoglycosides and also inhibits biofilm formation. To the best of our knowledge, it is the first time showing synergy between OBN and aminoglycosides against clinical and non-clinical S. aureus strains. No significant antimicrobial activity of OBN alone was observed against $S$. aureus with a MIC $32 \mathrm{mg} / \mathrm{mL}$. When OBN combined with aminoglycosides such as GEN, AMK, KAN, synergistic interactions were observed which was confirmed by microdilution checkerboard assay. These combinations remarkably reduced the MIC by $16(0.25 \mu \mathrm{g} / \mathrm{mL}), 8(0.5 \mu \mathrm{g} / \mathrm{mL}) 16$ folds $(1.0 \mu \mathrm{g} / \mathrm{mL})$ for GEN, AMK and KAN, respectively. In contrast, a FICI value $>0.5$ showed no similar interactions with AMP, VAN, TET to OBN. The synergistic boot up of OBN with aminoglycosides was further confirmed by spot analysis and also corroborated by cell viability analysis over time. The cells were completely eliminated with no significant viable cells $( \pm 2 \%)$ within $90 \mathrm{~min}$ OBN $(1 \mathrm{mg} / \mathrm{mL})$ treatment, combined either with GEN $(1 \mu \mathrm{g} /$ $\mathrm{mL})$ or KAN $(2 \mu \mathrm{g} / \mathrm{mL})$ respectively and $60 \mathrm{~min}$ in the presence of AMK $(1 \mu \mathrm{g} / \mathrm{mL})$. Remarkably, the cell 


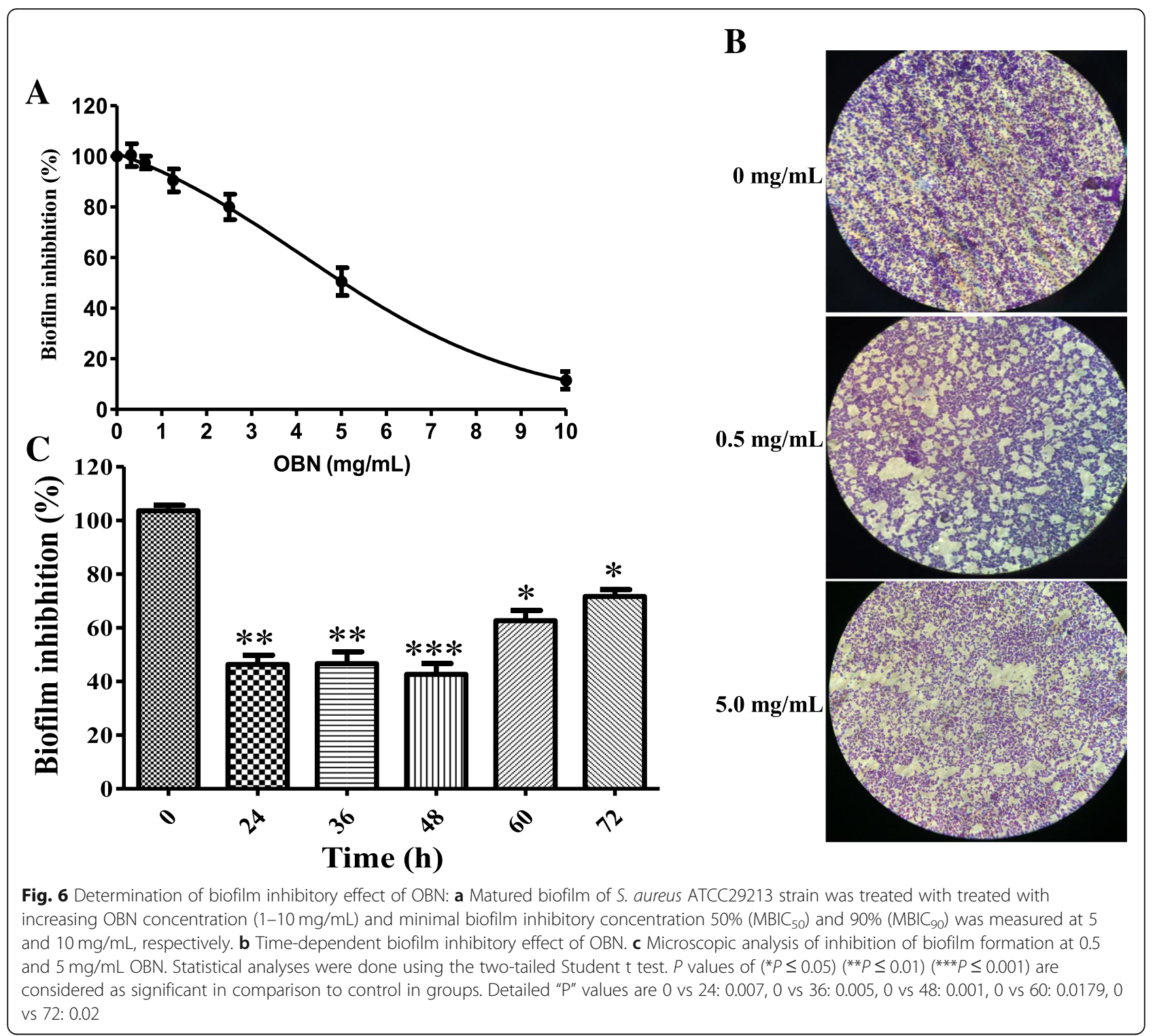

growth remained to suppress with no viable cell recovery observed even after $24 \mathrm{~h}$ long cells exposure under similar tested conditions. The induction of staphylocidal activity by OBN was attained at lower aminoglycosides concentrations by $4-16$ folds compared to their individual doses. Consequently, this lower dose requirement would be further helpful to decrease the clinical side effects of aminoglycoside as it causes ototoxicity affecting the vestibulo-cochlear system or nephrotoxicity. Clinically, aminoglycoside therapy for the treatment of staphylococcal infections in the inner wall endocarditis causes nephrotoxicity [43]. Other clinical limitation of combined therapy of aminoglycosides causes azotemia by increasing the level of nitrogenous substances such as urea, creatinine, various body waste compounds in the blood [44]. Investigations of more than one therapeutic agent in combination have been explored by the different set of studies $[16,17]$ and pragmatically a lucrative approach for the treatment of life-threatening resistant strains of $S$. aureus. The augmentation in drug potency of aminoglycosides has been previously reported to search an alternative treatment strategy against drug sensitive and resistant $S$. aureus.

Many studies have highlighted that cell membranetargeted agent or membrane potential factors enhanced the aminoglycoside uptake $[16,45,46]$. In order to investigate the aminoglycoside uptake, the intracellular GEN concentration was measured in presence of OBN. OBN that substantially induces the cell killing with aminoglycosides (GEN, KAN, and AMK), also potentiate GEN uptake by $66 \%$ as compared to control (without OBN). The enhancement of GEN uptake was further 


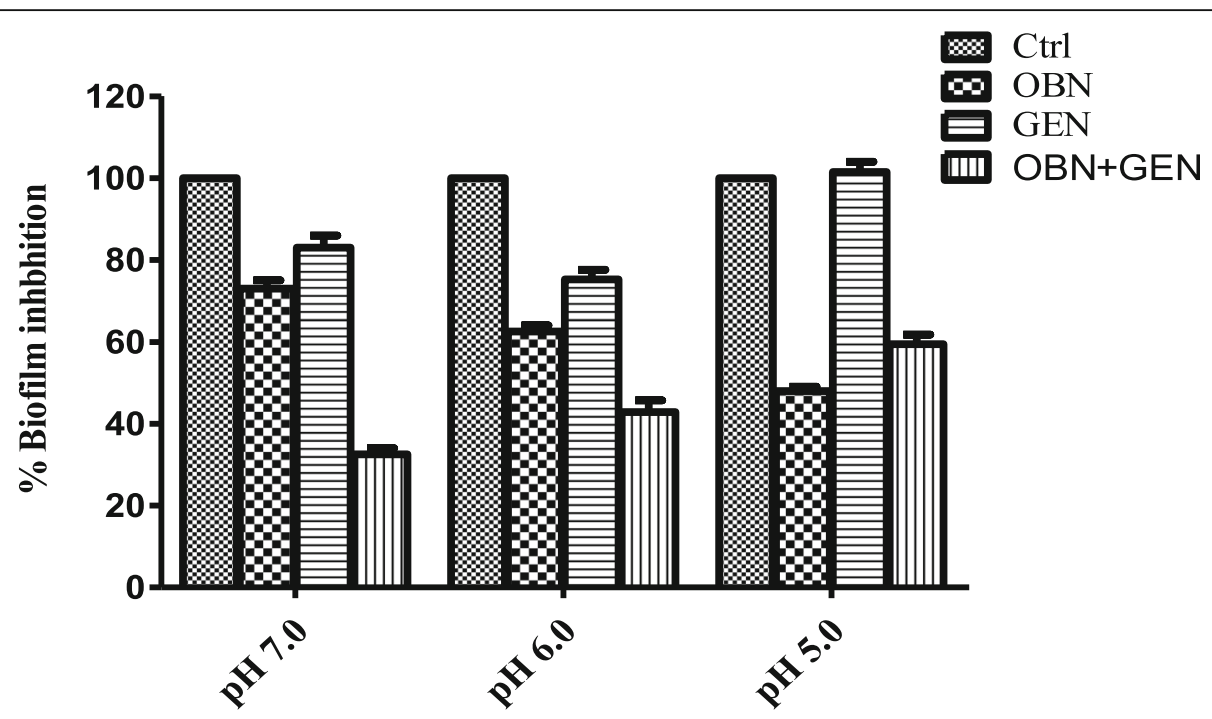

Fig. $7 \mathrm{pH}$ dependent biofilm inhibition effect of OBN. The pH-dependent inhibition of biofilm formation was determined by treating S. aureus ATCC29213 cells in the absence (control) and presence of $1 \mathrm{mg} / \mathrm{mL}$ OBN and GEN $(1.0 \mu \mathrm{g} / \mathrm{mL})$ either added alone or with their combinations at three 5.0, 6.0 and $7.0 \mathrm{pH}$. Statistical analyses were done using the two way Anova test. $P$ values of $(P \leq 0.05)(P \leq 0.01)$ are considered as significant in comparison to control groups. Detailed "P" values are Ctrl vs OBN 0.003, Ctrl vs Glu: 0.02, Ctrl vs OBN + Glu: 0.01

corroborated by reenergizing the starved cells with glucose $(10 \mathrm{mM})$ which remarkably increased GEN uptake by $50 \%$ with OBN. In contrast, the degree of GEN uptake was hampered and found to be similar to control when OBN treated cells were subsequently exposed with the crude membrane, isolated from S. aureus. Thereby, the GEN uptake was associated with the disturbance of cell membrane integrity and membrane integrity was somewhat mended upon addition of exogenous crude membrane. Likewise, OBN with GEN led to leakage of bacterial ATP showed that the membrane damaged which was also confirmed by nitrocefin assay. The consequence of $S$. aureus killing was associated with the accumulation of intracellular GEN upon alteration of membrane permeability by disturbing cell integrity [16].

Encasement of biofilm over cell boundary causes a major hurdle in the effective treatment as antibiotics failure to enter in the cells, resulting to emerge resistance to antibiotics and immune defence. Despite to higher drug-resistance, biofilm-forming cells tend to adhere to implanted medical devices and human tissues that majorly contribute to the acute and chronic infections. With a note, the biofilm attachment was disrupted by almost 80 and $50 \%$ with $5 \mathrm{mg} / \mathrm{mL}$ and $1.5 \mathrm{mg} / \mathrm{mL}$ OBN, respectively. The biofilm detachment was further validated by FITC and or blood plasma coated S. aureus cells analysis. OBN also showed inhibition in biofilm formation and it was inhibited by 50 and $90 \%$ at $5 \mathrm{mg} / \mathrm{mL}$ $\left(\mathrm{MBIC}_{50}\right)$ and $10 \mathrm{mg} / \mathrm{mL}\left(\mathrm{MBIC}_{90}\right)$ OBN. Of note, the inhibition of biofilm formation tends to increase upon longer exposure over $48 \mathrm{~h}$ OBN treatment. The biofilm inhibitory effect has reported previously in different studies [31]. Formation of biofilm is stable at near neutral $\mathrm{pH}$ and steadily decreases under acidic $\mathrm{pH}$. Formation of biofilm investigated with $\mathrm{OBN}$ in the presence or absence of GEN at 7.0, 6.0, $5.5 \mathrm{pH}$. As expected, the formation of biofilm was substantially reduced by $21 \pm 4 \%$, $37 \pm 5 \%$ and $55 \pm 5 \%$ at $7.0,6.05 .5 \mathrm{pH}$ respectively upon OBN $(2 \mathrm{mg} / \mathrm{mL})$ treatment. At $\mathrm{pH} 7.0$, biofilm inhibition was enhanced by $67 \pm 5 \%$ and no such effect was observed at pH 6.0 and 5.5 when both OBN added with GEN. Therefore, $S$. aureus showed resistant to GEN at lower $\mathrm{pH}$. Earlier study revealed that resistance of $S$. aureus to GEN is related to $\mathrm{pH}$ which affects the proton motive force. The uptake of GEN decreased at low $\mathrm{pH}$ is due to a decrease in the ATP level inside the cell [47].

\section{Conclusions}

Taken together, we established that OBN synergizes the antimicrobial activity of aminoglycosides that induces cell killing due to intracellular accumulation of GEN by disturbing cell homeostasis. It may be proven an effective approach for the treatment of staphylococcal infections.

\footnotetext{
Abbreviations

AMK: Amikacin; AMP: Ampicillin; ATP: Adenosine 5'-triphosphate; FIC: Fractional inhibitory concentration; FICl: Fractional inhibitory concentration index; FITC: Fluorescein iso-thiocyanate; GEN: Gentamycin; KAN: Kanamycin; MBIC: Minimal bioflim inhibitory concentration; MDR: Multidrug resistance; MIC: Minimal inhibitory concentration; MRSA: Methicillinresistant S. aureus; MSSA: Methicillin-sensitive S. aureus; OBN: Ouabain; TET: Tetracycline; VAN: Vancomycin
}

Acknowledgments

Sincere thanks to Prof. Rajendra Prasad for motivating us during the study. 


\section{Authors' contributions}

NK and AK designed the research, and NK, SS, VK, and SK performed the experiments and analysed the data. VK and AK wrote the manuscript. All the authors read and approved the final manuscript.

\section{Funding}

This study was funded by the Science \& Engineering Research Board (SERB), Department of Science \& Technology (DST), India (SB/EMEQ-278/2013, 29-10 2013) to Dr. Antresh Kumar.

\section{Availability of data and materials}

Data sharing not applicable to this article as no datasets were generated or analysed during the current study.

\section{Ethics approval}

This article does not contain any studies with human participants or animals performed by any of the authors.

\section{Consent for publication}

Not applicable.

\section{Competing interests}

The authors declare that they have no competing interests.

\section{Author details}

${ }^{1}$ Department of Biotechnology, Central University of South Bihar, Panchanpur, Gaya, Bihar 824236, India. ${ }^{2}$ National Institute of Plant Genome Research (NIPGR), New Delhi, India.

\section{Received: 4 February 2019 Accepted: 29 May 2019}

\section{Published online: 06 June 2019}

\section{References}

1. Koziel J, Maciag-Gudowska A, Mikolajczyk T, Bzowska M, Sturdevant DE, Whitney AR, Shaw LN, DeLeo FR, Potempa J. Phagocytosis of Staphylococcus aureus by macrophages exerts cytoprotective effects manifested by the upregulation of antiapoptotic factors. PLoS One. 2009;4:e5210.

2. Duin DV, Paterson D. Multidrug resistant Bacteria in the community : Trends and Lessons Learned. Infect Dis Clin North Am. 2016;30:377-90.

3. David MZ, Daum RS. Community-associated methicillin-resistant Staphylococcus aureus: epidemiology and clinical consequences of an emerging epidemic. Clin Microbiol Rev. 2010;23:616-87.

4. Sunagar R, Hegde NR, Archana GJ, Sinha AY. Prevalence and genotype distribution of methicillin-resistant Staphylococcus aureus (MRSA) in India. J Glob Antimicrobial Resist. 2016:7:46-52.

5. Bouchiat C, El-Zeenni N, Chakrakodi B, Nagaraj S, Arakere G, Etienne J. Epidemiology of Staphylococcus aureus in Bangalore, India: emergence of the ST217 clone and high rate of resistance to erythromycin and ciprofloxacin in the community. New Microbes New Infect. 2015;7:15-20.

6. Nagaraju U, Bhat G, Kuruvila M, Pai GS, Jayalakshmi BRP. Methicillin-resistant Staphylococcus aureus in community-acquired pyoderma. Int J Dermatol. 2004;43:412-4

7. Thati V, Shivannavar CT, Gaddad SM. Vancomycin resistance among methicillin resistant Staphylococcus aureus isolates from intensive care units of tertiary care hospitals in Hyderabad. Indian J Med Res. 2011;134:704-8.

8. Uematsu H, Yamashita K, Kunisawa S, Fushimi K, Imanaka Y. Estimating the disease burden of methicillin-resistant Staphylococcus aureus in Japan: retrospective database study of Japanese hospitals. PLoS One. 2017;12 e0179767.

9. Gilbert $P$, Allison DG, McBain AJ. Biofilms in vitro and in vivo: do singular mechanisms imply cross-resistance? J Appl Microbiol. 2002;92:98S-110S.

10. Kiedrowski MR, Horswill AR. New approaches for treating staphylococca biofilm infections. Ann N Y Acad Sci. 2011:1241:104-21.

11. Beenken KE, Blevins JS, Smeltzer MS. Mutation of sarA in Staphylococcus aureus limits biofilm formation. Infect Immun. 2003:71:4206-11.

12. Ohlsen K, Koller KP, Hacker J. Analysis of expression of the alpha-toxin gene (hla) of Staphylococcus aureus by using a chromosomally encoded hla::lacz gene fusion. Infect Immun. 1997;65:3606-14

13. Thangamani S, Mohammad H, Abushahba MFN, Hamed MI, Sobreira JPT, Hedrick VE, Paul LN, Seleem MN. Exploring simvastatin, an antihyperlipidemic drug, as a potential topical antibacterial agent. Sci Rep. 2015:5:article16407.

14. Younis W, Thangamani S, Seleem MN. Repurposing non-antimicrobial drugs and clinical molecules to treat bacterial infections. Curr Pharm Des. 2015:21: 4106-11.

15. Hu Y, Liu A, Vaudrey J, Vaiciunaite B, Moigboi C, McTavish SM, Kearns A, Coates A. Combinations of $\beta$-lactam or aminoglycoside antibiotics with Plectasin are synergistic against methicillin-sensitive and methicillin-resistant Staphylococcus aureus. PLoS One. 2015;12:e0117664.

16. Cunningham-Oakes E, Soren O, Moussa E, Rathor G, Liu Y, Coates A, Hu Y. Nordihydroguaiaretic acid enhances the activities of aminoglycosides against methicillin- sensitive and resistant Staphylococcus aureus in vitro and in vivo. Front Microbiol. 2015:6:article1195.

17. Hess DJ, Henry-Stanley MJ, Wells CL. Antibacterial synergy of glycerol Monolaurate and aminoglycosides in Staphylococcus aureus biofilms. Antimicrob Agents Chemother. 2014;58:6970-3.

18. Elemam A, Rahimian J, Doymaz M. In vitro evaluation of antibiotic synergy for Polymyxin B-resistant Carbapenemase-producing Klebsiella pneumonia. J Clin Microbiol. 2010:48:3558-62.

19. Hauptman PJ, Kelly RA. Digitalis. Circulation. 1999;99:1265-70.

20. Nicholls MG, Lewis LK, Yandle TG, Lord G, McKinnon W, Hilton PJ. Ouabain, a circulating hormone secreted by the adrenals, is pivotal in cardiovascular disease. Fact or fantasy? J Hypertens. 2009;27:3-8.

21. Simonini M, Pozzoli S, Bignami E, Casamassima N, Messaggio E, Lanzani C, Frati E, Botticelli IM, Rotatori F, Alfieri O, Zangrillo A, Manunta P. Endogenous Ouabain: an old Cardiotonic steroid as a new biomarker of heart failure and a predictor of mortality after cardiac surgery. Biomed Res Int. 2015:article714793.

22. Blaustein MP. The pump, the exchanger, and the holyspirit: origins and 40year evolution of ideas about the ouabain-Na+ pump endocrine system. Am J Physiol Cell Physiol. 2018;314:C3-C26.

23. Silva E, Soares-da-Silva P. New insights into the regulation of Na+K+-ATPase by Ouabain. Int Rev Cell Mol Biol. 2012;294:99-132

24. de Lores Arnaiz GR, Ordieres MGL. Brain Na+, K+-ATPase activity in aging and disease. Int J Biomed Sci. 2014;10:85-102

25. Nguyen AN, Jansson K, Sánchez G, Sharma M, Reif GA, Wallace DP, Blanco $\mathrm{G}$. Ouabain activates the Na-K-ATPase signalosome to induce autosomal dominant polycystic kidney disease cell proliferation. Am J Physiol Renal Physiol. 2011;301:F897-906.

26. Venugopal J, Blanco G. Ouabain enhances ADPKD cell apoptosis via the intrinsic pathway. Front Physiol. 2016;7:article107.

27. Xu ZW, Wang FM, Gao MJ, Chen XY, Hu WL, Xu RC. Targeting the $\mathrm{Na}(+) / \mathrm{K}(+$ )-ATPase alpha1 subunit of hepatoma HepG2 cell line to induce apoptosis and cell cycle arresting. Biol Pharm Bull. 2010;33:743-51.

28. Ozdemir T, Nar R, Kilinc V, Alacam H, Salis O, Duzgun A, Gulten S, Bedir A. Ouabain targets the unfolded protein response for selective killing of HepG2 cells during glucose deprivation. Cancer Biother Radiopharm. 2012 27:457-63.

29. Furstenwerth $\mathrm{H}$. Ouabain - the insulin of the heart. Int J Clin Pract. 2010;64: $1591-4$

30. Martins M, Viveiros M, Ordway D, Kristiansen JE, Molnar J, Amaral L. Reserpine, Ouabain and the Calcium Channel blocker verapamil, cause intracellular killing of Staphylococcus aureus. Res J Microbiol. 2006;1:203-9.

31. Kumar S, Kumar A, Kaushal M, Kumar P, Mukhopadhayay K, Kumar A. Fungal-derived xenobiotic exhibits antimicrobial and antibiofilm activity against Staphylococcus aureus. Drug Discov. 2018;12:214-23.

32. Mandal A, Kumar A, Singh A, Lynn AM, Kapoor K, Prasad R. A key structural domain of the Candida albicans Mdr1 protein. Biochem J. 2012:445:313-22.

33. El-Azizi M. Novel microdilution method to assess double and triple antibiotic combination therapy in vitro. Int J Microbiol. 2011:article4612021.

34. Sharma M, Manoharlal R, Negi AS, Prasad R. Synergistic anticandidal activity of pure polyphenol curcumin I in combination with azoles and polyenes generates reactive oxygen species leading to apoptosis. FEMS Yeast Res. 2010;10:570-8

35. Orhan G, Bayram A, Zer Y, Balci I. Synergy tests by E test and checkerboard methods of antimicrobial combinations against Brucella melitensis. J Clin Microbiol. 2005;43:140-3.

36. Jha S, Karnani N, Dhar SK, Mukhopadhayay K, Shukla S, Saini P, Mukhopadhayay G, Prasad R. Purification and characterization of the N-terminal nucleotide binding domain of an $\mathrm{ABC}$ drug transporter of Candida albicans: uncommon cysteine 193 of Walker a is critical for ATP hydrolysis. Biochem. 2003;42:10822-32. 
37. Borselli D, Blanchet M, Bolla J, Muth A, Skruber K, Otto P, Brunel JM. Motuporamine derivatives as antimicrobial agents and antibiotic enhancers against resistant gram-negative Bacteria. Chem Bio Chem. 2017;18:276-83.

38. Naveed S, Shah SN, Qamar F, Waheed N, Nazeer S. Simple UV spectrophotometric assay of new formulation gentamycin. J App Pharm. 2014;6:407-10

39. Kumar A, Shukla S, Mandal A, Shukla S, Ambudkar S, Prasad R. Divergent signature motifs of nucleotide binding domains of $A B C$ multidrug transporter, CaCdr1p of pathogenic Candida albicans, are functionally asymmetric and non-interchangeable. BBA Memb. 2010;1798:1757-66.

40. Arya R, Ravikumar R, Santhosh RS, Princy SA. SarA based novel therapeutic candidate against Staphylococcus aureus associated with vascular graft infections. Front Microbiol. 2015;6. https://doi.org/10.3389/fmicb.2015.00416.

41. Chopra L, Singh G, Jena KK, Sahoo DK. Sonorensin: a new bacteriocin with potential of an anti-biofilm agent and a food biopreservative. Sci Rep. 2015; 5:article13412.

42. Mataraci E, Dosler S. In vitro activities of antibiotics and antimicrobial cationic peptides alone and in combination against methicillin resistance Staphylococcus aureus biofilms. Antimicrob Agents Chemother. 2012;56: 6366-71.

43. Liu C, Bayer A, Cosgrove SE, Daum RS, Fridkin SK, Gorwitz RJ, Kaplan SL, Karchmer AW, Levine DP, Murray BE, Rybak M J, Talan DA, Chambers HF. Clinical practice guidelines by the infectious diseases society of America for the treatment of methicillin-resistant Staphylococcus aureus infections in adults and children. Clin Infect Dis. 2011;52:e18-55.

44. Fowler VG Jr, Boucher HW, Corey GR, Abrutyn E, Karchmer AW, Rupp ME, Levine DP, Chambers HF, Tally FP, Vigliani GA, Cabell CH, Link AS, DeMeyer I, Filler SG, Zervos M, Cook P, Parsonnet J, Bernstein JM, Price CS, Forrest GN, Fatkenheuer G, Gareca M, Rehm SJ, Brodt HR, Tice A, Cosgrove SE. Daptomycin versus standard therapy for bacteremia and endocarditis caused by Staphylococcus aureus. N Engl J Med. 2006;355:653-65.

45. Mitchell G, Lafrance M, Boulanger S, Seguin DL, Guay I, Gattuso M, Marsault E, Bouarab K, Malouin F. Tomatidine acts in synergy with aminoglycoside antibiotics against multiresistant Staphylococcus aureus and prevents virulence gene expression. J Antimicrob Chemother. 2012;67:559-68.

46. Allison KR, Brynildsen MP, Collins JJ. Metabolite-enabled eradication of bacterial persisters by aminoglycosides. Nature. 2011;473:216-20.

47. Henry-Stanley MJ, Hess DJ, Wells CL. Aminoglycoside inhibition of Staphylococcus aureus biofilm formation is nutrient dependent. J Med Microbiol. 2014;63:861-9.

\section{Publisher's Note}

Springer Nature remains neutral with regard to jurisdictional claims in published maps and institutional affiliations.

Ready to submit your research? Choose BMC and benefit from:

- fast, convenient online submission

- thorough peer review by experienced researchers in your field

- rapid publication on acceptance

- support for research data, including large and complex data types

- gold Open Access which fosters wider collaboration and increased citations

- maximum visibility for your research: over $100 \mathrm{M}$ website views per year

At BMC, research is always in progress.

Learn more biomedcentral.com/submissions 